\title{
Analisis Performansi Motor Induksi Satu Fasa Dengan Perbandingan Suplai Daya v/f Konstan Pada Blower Dengan Menggunakan Matlab
}

\section{Performance Analysis of One Phase Induction Motor with the Ratio of Constant Power Supply v/f in Blower by Using Matlab}

\author{
Mhd. Fahmi Syawali Rizki \\ Program Studi Teknik Elektro, Fakultas Teknik, Universitas Sumatera Utara, Indonesia \\ Diterima: Maret 2019; Disetujui: April 2019; Dipublikasi: April 2019 \\ *Coresponding Email: mfahmi.syawali@yahoo.com
}

\begin{abstract}
Abstrak
Motor induksi satu fasa dengan perbandingan suplai daya V/f konstan dapat dilakukan dengan pengaturan frekuensi jala-jala yang masuk ke kumparan stator melalui suatu rangkaian converterinverter. Dengan perbandingan suplai daya V/f yang konstan dapat dihasilkan torsi yang besar dengan putaran yang kecil. Putaran yang kecil hanya membutuhkan daya masukan yang kecil. Sehingga untuk menghasilkan torsi yang besar untuk menggerakkan beban cukup dengan memberikan daya masukan yang kecil dan penghematan energi listrik dapat dilakukan. Penelitian ini akan menganalisis secara teoritis performansi motor induksi satu fasa untuk aplikasi blower dengan perbandingan suplai daya $\mathrm{V} / \mathrm{f}$ yang konstan. Motor induksi satu fasa yang digunakan adalah jenis motor kapasitor permanen untuk menjalankan daya horse power fraksional dari blower. Melalui simulasi komputer yang dilaksanakan dapat dihitung performansi motor induksi satu fasa seperti efisiensi dan torsi motor terhadap putaran dengan perbandingan V/f yang konstan. Oleh karena itu penulis menggunakan program Matlab untuk dapat melakukan perhitungan dan penggambaran secara akurat karakteristik dari motor induksi satu fasa tersebut. Sehingga diharapkan hasilnya dapat menjadi salah satu alternatif dalam pengaturan kecepatan motor induksi satu fasa pada aplikasi blower.
\end{abstract}

Kata Kunci: Motor Induksi Satu Fasa, Suplai Daya V/f Konstan, Blower, Matlab

\begin{abstract}
A single phase induction motor with a comparison of the constant $V / f$ power supply can be done by setting the mesh frequency that enters the stator coil through a converter-inverter circuit. By comparison the constant $V / F$ power supply can produce a large torque with a small rotation. A small rotation requires only a small input power. So that to produce a large torque to drive enough load by providing a small input power and saving electricity can be done. This final project will theoretically analyze the performance of a single phase induction motor for blower applications with a constant ratio of $V / f$ power supply. The one phase induction motor used is a type of permanent capacitor motor to run fractional horse power from the blower. Through computer simulations carried out, one-phase induction motor performance can be calculated such as motor efficiency and torque to rotation with a constant $V /$ fratio. Therefore, the author uses the Matlab program to be able to accurately calculate and describe the characteristics of the one phase induction motor.
\end{abstract}


Mhd. Fahmi Syawali Rizki, Analisis Performansi Motor Induksi Satu Fasa Dengan Perbandingan

So it is expected that the results can be an alternative in setting the speed of a single phase induction motor in a blower application.

Keywords : One Phase Induction Motor, Constant V/f Power Supply, Blower, Matlab

How to Cite: Rizki, M, F, S, (2019), Analisis Performansi Motor Induksi Satu Fasa Dengan Perbandingan Suplai Daya v/f Konstan Pada Blower Dengan Menggunakan Matlab (Performance Analysis of One Phase Induction Motor with the Ratio of Constant Power Supply v/f in Blower by Using Matlab), JESCE (Journal or Electrical and System Control Engineering),2(2):80-97 


\section{PENDAHULUAN}

Motor induksi satu fasa adalah motor induksi yang beroperasi pada sumber arus bolak balik satu fasa (Chapman, 1999). Motor induksi satu fasa umumnya mempunyai rotor sangkar. Motor induksi satu fasa ini tidak mampu melakukan pengasutan sendiri (self starting), oleh karena itu motor ini membutuhkan peralatan bantu untuk menghasilkan momen putar awal, sehingga motor dapat berjalan secara kontinu.

Motor induksi satu fasa yang digunakan untuk aplikasi blower adalah jenis motor kapasitor permanen. Motor kapasitor permanen mempunyai kapasitor yang secara permanen dihubungkan seri dengan belitan bantu dan paralel dengan belitan utama. Belitan bantu untuk pengasutan awal motor tetap terhubung dengan belitan utama ketika motor berjalan.

Motor kapasitor permanen dengan perbandingan suplai daya V/f konstan dapat dilakukan dengan pengaturan frekuensi jalajala yang masuk ke kumparan stator melalui suatu rangkaian inverter. Dengan pengaturan frekuensi jala-jala ini dapat menghasilkan torsi yang besar dengan putaran yang kecil. Putaran yang kecil hanya membutuhkan daya masukan yang kecil, sehingga untuk menghasilkan torsi yang besar untuk menggerakkan beban cukup dengan memberikan daya masukan yang kecil dan penghematan energi listrik dapat dilakukan.

Penelitian ini menganalisis performansi dari motor kapasitor permanen dengan merubah-ubah tegangan dan frekuensi masukan dengan perbandingan yang konstan, sehingga diperoleh karakteristik performansi motor kapasitor permanen dengan perbandingan suplai daya V/f konstan.

\section{Motor Induksi Satu Phasa}

Motor induksi satu fasa sering digunakan sebagai penggerak pada peralatan yang memerlukan daya rendah dan kecepatan yang relatif konstan. Hal ini disebabkan karena motor induksi satu fasa memiliki beberapa kelebihan yaitu konstruksi yang cukup sederhana, kecepatan putar yang hampir konstan terhadap perubahan beban, dan umumnya digunakan pada sumber jalajala satu fasa yang banyak terdapat pada peralatan listrik domestik. Walaupun demikian motor ini juga memiliki beberapa kekurangan, yaitu kapasitas pembebanan yang relatif rendah, tidak dapat melakukan pengasutan sendiri tanpa pertolongan alat bantu dan efisiensinya yang rendah. Konstruksi motor induksi satu fasa hampir sama dengan motor induksi fasa banyak, yaitu terdiri dari dua bagian utama yaitu stator dan rotor (Chapman, 1999). Keduanya merupakan 
rangkaian magnetik yang berbentuk silinder dan simetris. Di antara rotor dan stator ini terdapat celah udara yang sempit. Stator merupakan bagian yang diam sebagai rangka tempat kumparan stator terpasang. Bagian ini terdiri atas : inti stator, kumparan stator dan alur stator. Motor induksi satu fasa dilengkapi dengan dua kumparan stator yang dipasang terpisah, yaitu kumparan utama atau sering disebut dengan kumparan berputar dan kumparan bantu yang sering disebut dengan kumparan start.

Rotor merupakan bagian yang berputar. Bagian ini terdiri atas inti rotor, belitan rotor dan alur rotor. Terdapat dua jenis rotor yaitu rotor belitan (wound rotor) dan rotor sangkar ( squirrel cage rotor)

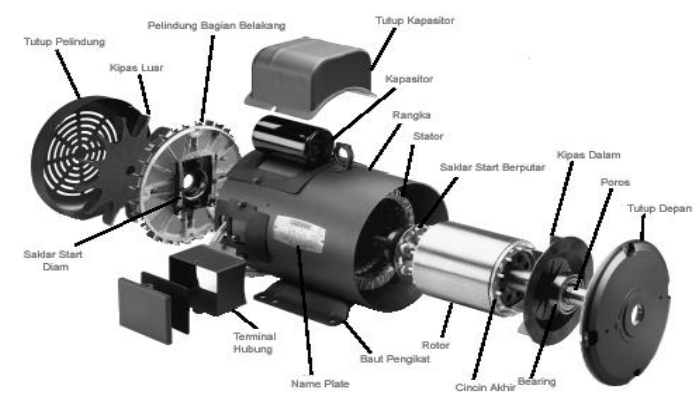

Gambar 1 Komponen Dasar dari Motor Induksi Satu

Fasa

Prinsip kerja motor induksi satu fasa dapat dijelaskan dengan menggunakan teori medan putar silang (cross-field theory) (Julian, 1995). Jika suatu motor induksi satu fasa diberikan tegangan ac satu fasa maka arus sinusiodal terhadap waktu akan mengalir pada belitan tersebut. Arus stator ini akan menghasilkan medan magnet seperti yang ditunjukkan oleh garis putus-putus pada gambar 2 dibawah:

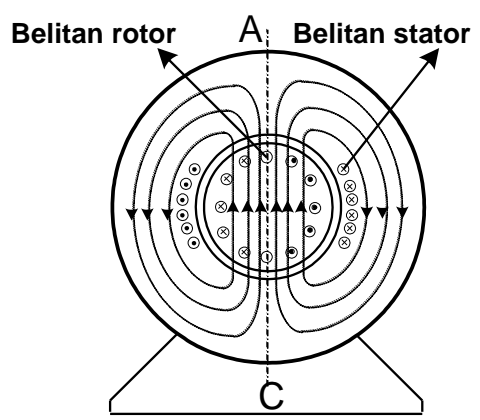

Gambar 2 Medan Magnet Stator Berpulsa Sepanjang Garis AC

Arus stator yang mengalir pada setengah periode pertama akan membentuk kutub utara di A dan kutub selatan di $\mathrm{C}$ pada permukaan stator. Pada setengah perode berikutnya, arah kutub-kutub stator menjadi terbalik. Meskipun kuat medan magnet stator adalah selalu berubah-ubah yaitu maksimum pada saat arus maksimum dan nol pada saat arus nol dan polaritasnya berbalik secara periodik, aksi ini hanya terjadi sepanjang sumbu AC. Dengan demikian, medan magnet ini tidak berputar tetapi hanya merupakan sebuah medan magnet berpulsa pada posisi yang tetap (stationary).

Seperti halnya pada transformator, tegangan terinduksi pada belitan sekunder, 
dalam hal ini belitan rotor. Karena rotor dari motor induksi satu fasa adalah rotor sangkar dimana belitannya telah terhubung singkat, maka aruspun mengalir. Sesuai dengan hukum Lenz, arah dari arus ini (seperti yang ditunjukkan pada gambar 2) adalah sedemikian rupa sehingga medan magnet yang dihasilkannya menentang medan magnet yang menghasilkannya. Arus rotor ini akan menghasilkan medan magnet rotor dan membentuk kutub-kutub pada permukaan rotor. Karena kutub-kutub ini juga berada pada sumbu AC dengan arah yang berlawanan terhadap kutub-kutub stator, maka tidak ada momen putar yang dihasilkan pada kedua arah, rotor tetap diam. Dengan demikian, motor induksi satu fasa tidak dapat diasut sendiri dan membutuhkan rangkaian bantu untuk menjalankannya seperti yang ditunjukkan pada gambar 3 dibawah :

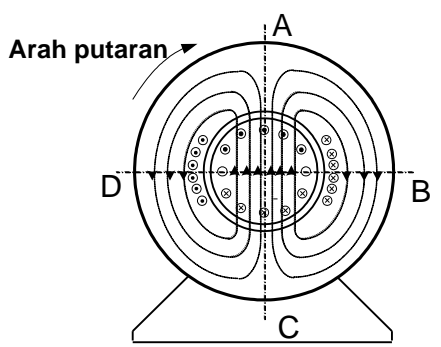

Gambar 3 Motor Dalam Keadaan Berputar

Misalnya sekarang motor sedang berputar. Hal ini dapat dilakukan dengan memutar rotor dengan tangan ataupun dengan rangkaian bantu. Konduktor-konduktor rotor memotong medan magnet stator sehingga timbul gaya gerak listrik pada konduktorkonduktor tersebut. Hal ini diperlihatkan pada gambar 3 yang menunjukkan rotor sedang berputar searah jarum jam.

Jika fluks stator seperti yang diperlihatkan pada gambar 3 mengarah ke atas, maka sesuai dengan kaidah tangan kanan Fleming, arah gaya gerak listrik (ggl) rotor akan mengarah keluar kertas pada setengah bagian atas rotor dan mengarah ke dalam kertas pada setengah bagian bawah rotor. Pada setengah periode berikutnya arah dari gaya gerak listrik yang dibangkitkan akan terbalik. Gaya gerak listrik yang diinduksikan ke rotor adalah berbeda dengan arus dan fluks stator. Karena konduktor-konduktor rotor terbuat dari bahan dengan tahanan rendah dan induktansi tinggi, maka arus rotor yang dihasilkan akan tertinggal terhadap gaya gerak listrik rotor mendekati $90^{\circ}$.

\section{Teori Medan Putar Ganda}

Teori medan putar ganda (double revolving-field theory) adalah suatu metode lain untuk menganalisa prinsip perputaran motor induksi satu fasa disamping teori medan putar silang (Julian, 1995). Menurut teori ini, medan magnet yang berpulsa dalam waktu tetapi diam dalam ruangan dapat dibagi menjadi dua medan magnet, dimana besar 
kedua medan magnet itu sama dan berputar dengan berlawanan arah. Dengan kata lain, suatu fluks sinusoidal bolak-balik dapat diwakili oleh dua fluks yang berputar, yang masing-masing besarnya sama dengan setengah dari nilai fluks bolak-balik tersebut dan masing-masing berputar secara sinkron dengan arah berlawanan.

Pada gambar 4.a. menunjukkan suatu fluks bolak-balik yang mempunyai nilai maksimum $\quad \phi_{\mathrm{m}} . \quad$ Komponen-komponen fluksnya A dan B mempunyai nilai yang sama yaitu $\phi_{\mathrm{m}} / 2$, berputar dengan arah yang berlawanan dan searah perputaran jarum jam, seperti ditunjukkan anak panah.

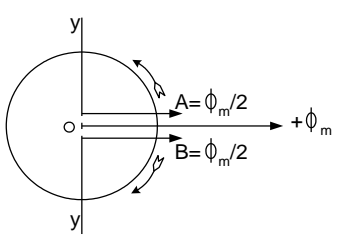

(a)

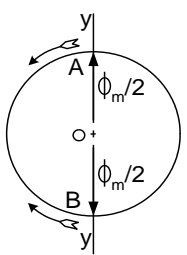

(b)

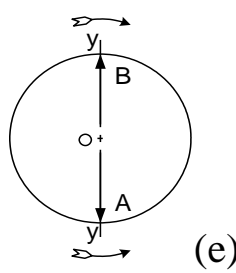

Gambar 4 Konsep Medan Putar Ganda
Pada beberapa saat ketika A dan B telah berputar dengan sudut $+\theta$ dan $-\theta$ seperti pada gambar 2.7.b, maka besar fluks resultannya adalah :

$$
\begin{gathered}
\phi_{r}^{2}=\frac{\phi_{m}^{2}+\phi_{m}^{2}}{4}-\frac{2 \phi_{m} \phi_{m}}{2 \cdot 2} \cos 2 \theta \\
\phi_{r}=\phi_{m} \sin \theta
\end{gathered}
$$

dimana :

$$
\begin{aligned}
& \phi_{r}=\text { fluks resultan } \\
& \phi_{m}=\text { fluks maksimum } \\
& \theta \quad=\text { sudut ruang }
\end{aligned}
$$

Setelah seperempat periode putaran, fluks A dan B akan berlawanan arah seperti yang ditunjukkan pada gambar 2.7.c, sehingga resultan fluksnya sama dengan nol. Setelah setengah periode putaran, fluks A dan B akan mempunyai resultan sebesar $-2 \times \phi_{\mathrm{m}} / 2=-\phi_{\mathrm{m}}$, seperti yang ditunjukkan oleh gambar 2.7.d. Setelah tiga perempat putaran, resultannya akan kembali nol seperti yang ditunjukkan pada gambar 2.7.e dan demikianlah seterusnya. Jika nilai-nilai dari fluks resultan digambarkan terhadap $\theta$ diantara $\theta=0^{\circ}$ sampai $\theta=360^{\circ}$, maka akan didapat suatu kurva seperti yang ditunjukkan pada gambar 2.8 


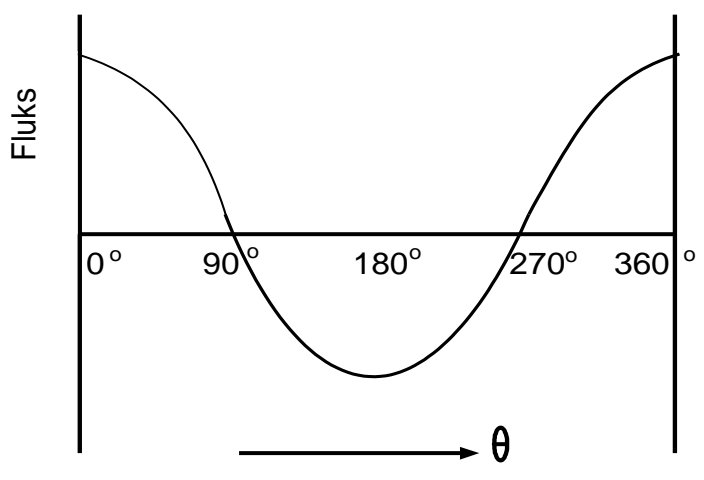

Gambar 5 Kurva Fluks Resultan Terhadap $\theta$

Pada saat rotor berputar sesuai dengan arah momen putar medan maju dengan kecepatan tertentu, maka besar slip terhadap momen putar medan maju $\left(\mathrm{S}_{\mathrm{f}}\right)$ yang terjadi adalah :

$$
\begin{aligned}
\mathrm{S}_{\mathrm{f}}=\frac{\mathrm{n}_{\mathrm{s}}-\mathrm{n}_{\mathrm{r}}}{\mathrm{n}_{\mathrm{s}}}= & \mathrm{s} \\
\operatorname{dimana}: n_{s}= & \text { kecepatan sinkron } \\
n_{r}= & \text { kecepatan putaran } \\
& \text { Rotor }
\end{aligned}
$$

Sedangkan slip terhadap momen putar medan mundur $\left(\mathrm{S}_{\mathrm{b}}\right)$ dengan rotor menentang arah momen putar mundur adalah :

$$
\begin{aligned}
& \mathrm{S}_{\mathrm{b}}=\frac{\mathrm{n}_{\mathrm{s}}-\left(-\mathrm{n}_{\mathrm{r}}\right)}{\mathrm{n}_{\mathrm{s}}}=\frac{2 \mathrm{n}_{\mathrm{s}}-\left(\mathrm{n}_{\mathrm{s}}-\mathrm{n}_{\mathrm{r}}\right)}{\mathrm{n}_{\mathrm{s}}} \\
& S_{b}=2-s \ldots \ldots \ldots \ldots \ldots \ldots \ldots \ldots \ldots \ldots \ldots \ldots \ldots \ldots \ldots \ldots \ldots \ldots \ldots \ldots
\end{aligned}
$$

Masing-masing dari kedua komponen fluks tersebut memotong konduktor rotor sehingga menginduksikan ggl dan pada akhirnya menghasilkan torsi tersendiri. Kedua torsi mempunyai arah yang saling berlawanan seperti yang ditunjukkan pada gambar 2.9. Pada keadaan diam kedua komponen torsi tersebut sama besarnya, sehingga torsi resultan asut adalah nol. Pada saat motor berputar, besar kedua komponen torsi tesebut tidaklah sama sehingga torsi resultan membuat motor tetap berputar pada putarannya.

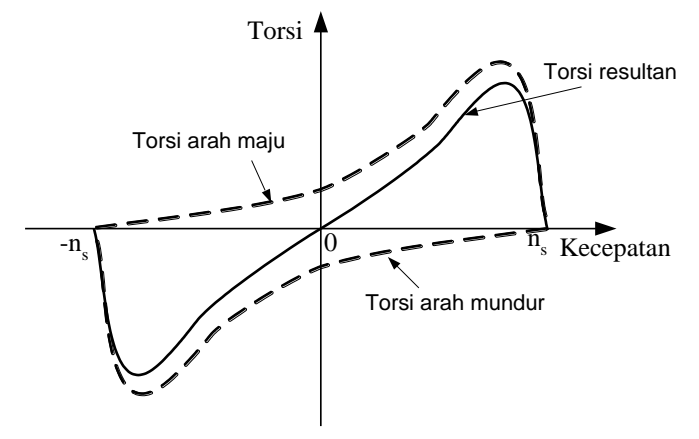

Gambar 6 Karakteristik Torsi - Kecepatan Motor Induksi Satu Fasa

\section{Aplikasi Motor Induksi Satu Fasa pada Blower}

Penghembus udara atau sering juga disebut dengan blower digunakan pada tempat residensial pemanasan dan pendinginan udara (Heating and Conditioning) dengan ciri kerja dalam bentuk pemanasan, pendinginan dan sirkulasi udara.

Blower dapat dikelompokkan menurut kenaikan tekanan yang ditimbulkan ketika menyedot udara. Menurut Theraja (1979), pada umumnya, blower dengan tekanan kerja 
kurang dari $73,8 \mathrm{mmHg}$ disebut juga kipas angin, dan yang tekanan kerjanya $73,8 \mathrm{mmHg}$ sampai kurang dari $738 \mathrm{mmHg}$ disebut blower dalam tipe turbo dan tipe pergeseran yang menurut prinsip kerjanya sebagai berikut:

1. Tipe turbo: Impeler diputar dengan kecepatan tinggi, untuk memperbesar momentum gas yang melalui sudu dan dengan itu memperbesar tekanan dan kecepatan gas. Ada tipe aliran aksial dan tipe sentrifugal.

2. Tipe pergeseran (displacement): Sejumlah gas tertutup dan volume dikurangi untuk memperbesar tekanan. Ada tipe berputar dan tipe torak.

\begin{tabular}{|c|c|c|c|}
\hline \multicolumn{2}{|c|}{ Jenis } & $\begin{array}{l}\text { Kipas } \\
\text { angin } \\
(<73,8\end{array}$ & $\begin{array}{c}\text { Blower } \\
(73,8- \\
738\end{array}$ \\
\hline \multirow{4}{*}{ Turbo } & $\begin{array}{l}\text { Aliran } \\
\text { aksial }\end{array}$ & $\begin{array}{l}\text { Kipas } \\
\text { angin } \\
\text { aliran } \\
\text { aksial }\end{array}$ & $\begin{array}{l}\text { Blower } \\
\text { aliran } \\
\text { aksial }\end{array}$ \\
\hline & \multirow{3}{*}{ Sentrifugal } & $\begin{array}{l}\text { Kipas } \\
\text { angin } \\
\text { sudu } \\
\text { jamak }\end{array}$ & \\
\hline & & $\begin{array}{l}\text { Kipas } \\
\text { angin } \\
\text { radial }\end{array}$ & $\begin{array}{c}\text { Blower } \\
\text { radial }\end{array}$ \\
\hline & & $\begin{array}{l}\text { Kipas } \\
\text { angin } \\
\text { turbo }\end{array}$ & $\begin{array}{c}\text { Blower } \\
\text { turbo }\end{array}$ \\
\hline Pergeseran & Berputar & & $\begin{array}{c}\text { Blower } \\
\text { root }\end{array}$ \\
\hline
\end{tabular}

Untuk aplikasi blower ini motor induksi satu fasa yang paling banyak digunakan jenis motor kapasitor permanen sebagai penggerak utama sudu atau kipas. Hal ini karena motor kapasitor permanen memiliki kelebihan yaitu faktor daya dan efisiensi yang lebih baik saat motor berputar, lebih halus dan tidak berisik dalam pengoperasiannya. 
Berikut ini adalah gambar pemakaian motor kapasitor permanen untuk aplikasi blower satu tingkat :

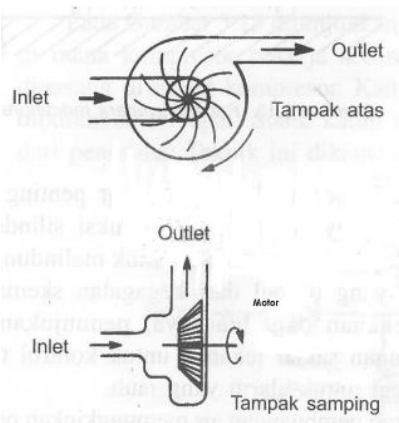

(a) Jenis sentrifugal

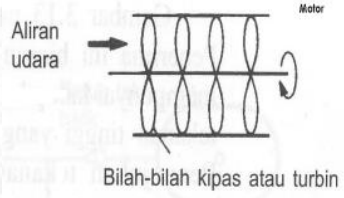

(b) Jenis aksial
Gambar 7 Penggunaan Motor Kapasitor Permanen pada Blower

\section{Motor Induksi Satu Fasa Dengan} Perbandingan Suplai Daya V/f Konstan

Ada dua teknik untuk mengatur kecepatan motor induksi. Salah satunya adalah memvariasikan kecepatan sinkron, yang merupakan kecepatan medan putar stator. Kecepatan rotor selalu mendekati kecepatan sinkronnya $n_{\text {sync. }}$. Teknik yang lain adalah memvariasikan slip motor untuk setiap beban yang diberikan.

Persamaan kecepatan sinkron motor induksi adalah

$$
\mathrm{n}_{\mathrm{s}}=\frac{120 \mathrm{f}}{\mathrm{p}}
$$

dimana $: \mathrm{f}=$ frekuensi suplai ke motor $\mathrm{p}=$ jumlah kutub motor sehingga cara yang dilakukan untuk memvariasikan kecepatan sinkron mesin adalah dengan :

a. mengubah jumlah kutub

b. mengubah frekuensi listrik (frekuensi jalajala)

Mengatur slip dapat dilakukan dengan :

i. mengatur tahanan rotor (tahanan luar).

). mengatur tegangan terminal motor (tegangan jala-jala).

\section{Pengaturan Putaran Dengan Variasi}

\section{Tegangan Terminal Motor}

$$
\begin{gathered}
\mathrm{T}=\frac{60\left[\left(\mathrm{I}_{1}^{2}+\mathrm{a}^{2} \mathrm{I}_{2}^{2}\right)\left(\mathrm{R}_{\mathrm{f}}-\mathrm{R}_{\mathrm{b}}\right)+2 \mathrm{a}\left(\mathrm{R}_{\mathrm{f}}+\mathrm{R}_{\mathrm{b}}\right) \mathrm{I}_{1} \mathrm{I}_{2} \sin \theta_{21}\right]}{2 \pi \mathrm{n}_{\mathrm{s}}} \\
\operatorname{dimana}: \tilde{I}_{1}=\frac{\tilde{V}_{1}\left(\hat{Z}_{22}-\hat{Z}_{12}\right)}{\hat{Z}_{11} \hat{Z}_{22}-\hat{Z}_{12} \hat{Z}_{21}} \\
\tilde{I}_{2}=\frac{\tilde{V}_{1}\left(\hat{Z}_{11}-\hat{Z}_{21}\right)}{\hat{Z}_{11} \hat{Z}_{22}-\hat{Z}_{12} \hat{Z}_{21}}
\end{gathered}
$$

Maka torsi yang dihasilkan motor kapasitor permanen akan sebanding dengan kuadrat tegangan. Dengan memvariasikan tegangan suplai ke motor, maka torsi dan kecepatan sinkron motor akan bervariasi juga. Sehingga karakteristik torsi-kecepatan motor dapat diatur dengan melebihi batasannya dengan memvariasikan tegangan jala-jala. Metode pengaturan kecepatan ini digunakan pada motor-motor kecil sebagai penggerak kipas (driving fan). Dapat dilihat pada gambar 
8 yaitu Grafik Torsi Terhadap Kecepatan pada Pengaturan Kecepatan Dengan Memvariasikan Tegangan.

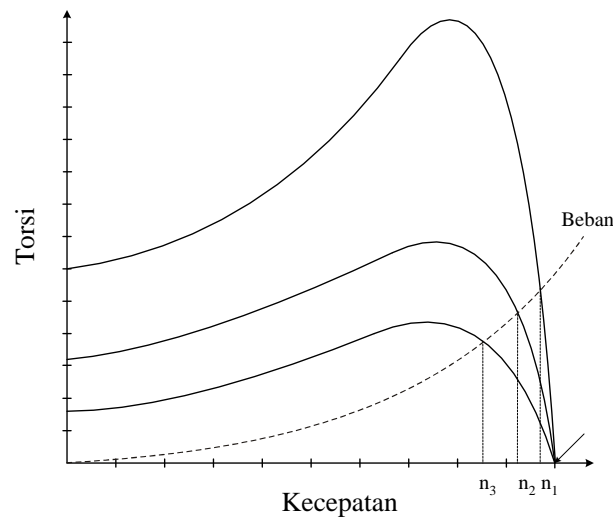

Gambar 8 Grafik Torsi Terhadap Kecepatan pada Pengaturan Kecepatan Dengan Memvariasikan

Tegangan

\section{Pengaturan Kecepatan Dengan Variasi Suplai Frekuensi Listrik}

Kecepatan motor induksi dapat dikontrol dengan memvariasikan frekuensi jala-jala. Untuk menjaga agar kerapatan fluks tetap mendekati konstan, tegangan jala-jala juga divariasikan sebanding dengan frekuensi. Torsi maksimumnya akan sangat mendekati konstan. Motor induksi yang menggunakan cara ini mempunyai karakterisitk yang sama dengan motor dc penguatan bebas dengan fluksi yang konstan dan tegangan jangkar yang bervariasi.

Masalah terbesar adalah menentukan nilai pengaturan frekuensi yang effektif dan ekonomis. Salah satu cara adalah menggunakan mesin induksi rotor belitan sebagai pengubah frekuensi. Cara lain adalah menggunakan converter frekuensi solid state sebagaimana yang ditunjukkan pada Gambar 9 dibawah:

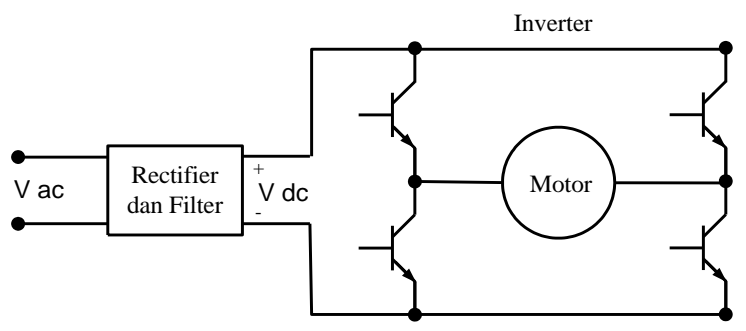

Gambar 9 Rangkaian Pengaturan Kecepatan Motor Dengan Memvariasikan Frekuensi

Prinsip Dasar Motor Induksi Satu Fasa Dengan Perbandingan Suplai Daya V/f Konstan

Jika frekuensi listrik pada stator motor induksi diubah-ubah, tingkat putaran medan magnetnya $\left(n_{\text {sync }}\right)$ akan berubah-ubah sebanding dengan perubahan frekuensi listriknya dan titik beban nol pada kurva karakteristik torsi-kecepatan akan berubah juga (Guru, 1998). Kecepatan Sinkron $\left(n_{\text {sync }}\right)$ motor induksi pada kondisi nominal disebut sebagai kecepatan dasar (base speed). Dengan menggunakan pengaturan frekuensi yang berubah-ubah dapat diatur kecepatan motor di atas atau di bawah kecepatan dasar. Sebuah penggerak motor induksi dengan frekuensi 
yang dapat diubah- ubah, dapat mengatur kecepatan motor induksi dalam selang $5 \%$ kecepatan dasar sampai 2 kali kecepatan dasar. Namun, dikarenakan perubahan frekuensi, sangat penting untuk menjaga batasan tegangan dan torsi motor demi keamanan operasi. Ketika motor dijalankan pada kecepatan di bawah kecepatan dasar, sangat penting untuk mengurangi tegangan stator untuk operasi yang tepat. Tegangan stator harus diturunkan sebanding dengan penurunan frekuensi. Ketika frekuensi listrik motor dibuat melebihi rating frekuensi motor, tegangan stator dijaga pada nilai nominal.

Walaupun pertimbangan masalah kejenuhan masih mengijinkan tegangan dinaikkan nilai ratingnya, pada kondisi ini perlu dibatasi tegangan tersebut untuk melindungi isolasi belitan motor. Gambar dibawah adalah karakteristik kurva Torsi Kecepatan untuk semua frekuensi. Dibawah ini adalah gambar karakteristik kurva TorsiKecepatan untuk semua frekuensi.

\author{
Gambar 10 Karakteristik Kurva Torsi-Kecepatan \\ Untuk Semua Frekuensi
}

\section{METODE PENELITIAN}

Pengaturan kecepatan motor induksi satu fasa pada blower dipergunakan agar memperoleh variasi kecepatan pada kondisi tertentu sesuai dengan kebutuhan tekanan udara yang diperlukan, sehingga blower dapat dipergunakan tidak hanya pada satu kondisi. Hal ini dilakukan dengan menjaga torsi motor tetap konstan. Performansi motor induksi satu fasa yang dipakai pada blower akan dianalisis untuk tiap-tiap frekuensi yang berbeda di bawah frekuensi rating adalah sebagai berikut

1. Karakteristik torsi terhadap kecepatan

2. Karakteristik daya output terhadap kecepatan

3. Karakteristik arus kumparan utama terhadap kecepatan

4. Karakteristik arus kumparan bantu terhadap kecepatan

5. Karakteristik arus masukan terhadap kecepatan

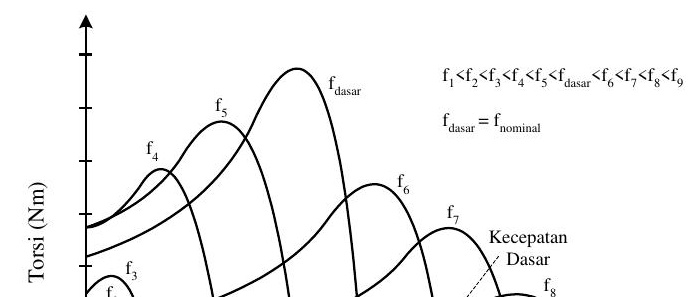


Mhd. Fahmi Syawali Rizki, Analisis Performansi Motor Induksi Satu Fasa Dengan Perbandingan

6. Karakteristik faktor daya masukan terhadap kecepatan

7. Karakteristik daya input terhadap kecepatan

8. Karakteristik tegangan kapasitor terhadap kecepatan

9. Karakteristik efisiensi terhadap kecepatan

Untuk mendapatkan karakteristikkarakteristik di atas dengan akurat maka perhitungan performansi motor induksi satu fasa di atas dilakukan dengan menggunakan program Matlab.

Data-data motor induksi satu fasa yang digunakan sebagai data masukan ke dalam perhitungan adalah berupa data pengujian motor blower tersebut, yaitu sebagai berikut :

a. Data name plate motor blower :

EWG Motor Type AMEB 80FY4R3

$>$ Tipe : Permanent Split Capacitor Motor (PSC Motor)

$$
\begin{array}{ll}
0,75 \mathrm{~kW} & \mathrm{~V}_{\mathrm{t}}=220 \mathrm{~V} \\
\mathrm{f}=50 \mathrm{~Hz} & \mathrm{p}=4 \\
\mathrm{C}=25 \mu \mathrm{F} / 400 \mathrm{~V} & \mathrm{I}=6,3 \mathrm{Amp}
\end{array}
$$

Kelas Motor : $\mathrm{B} \quad \mathrm{n}=1370 \mathrm{rpm}$

Fasa $=1$

b. Data-data hasil pengujian motor :

Tabel 2 Data-data Pengujian Motor Blower 
DIAGRAM ALUR PENELITIAN

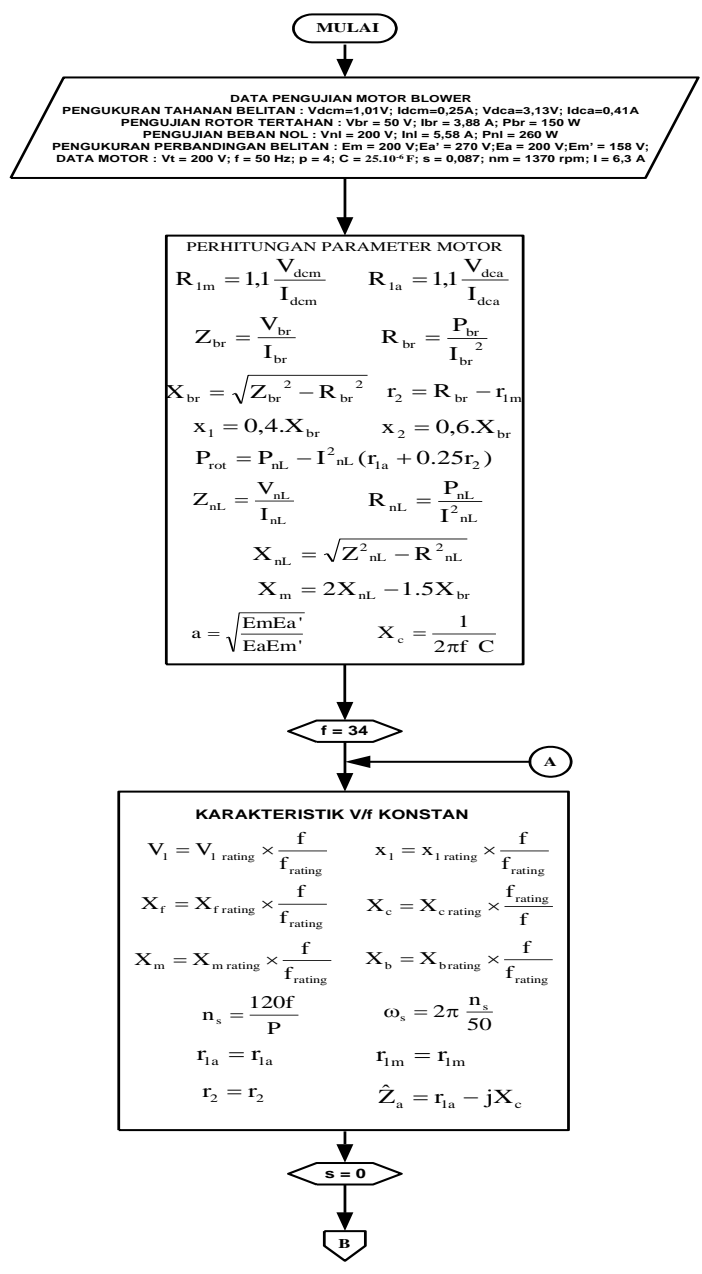

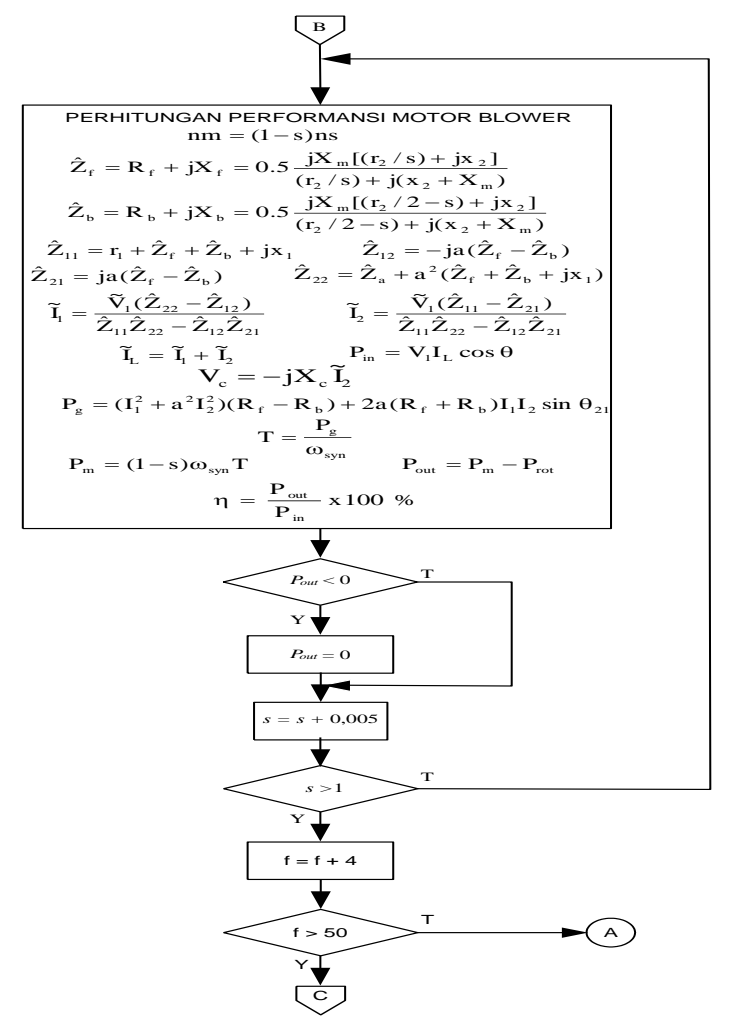

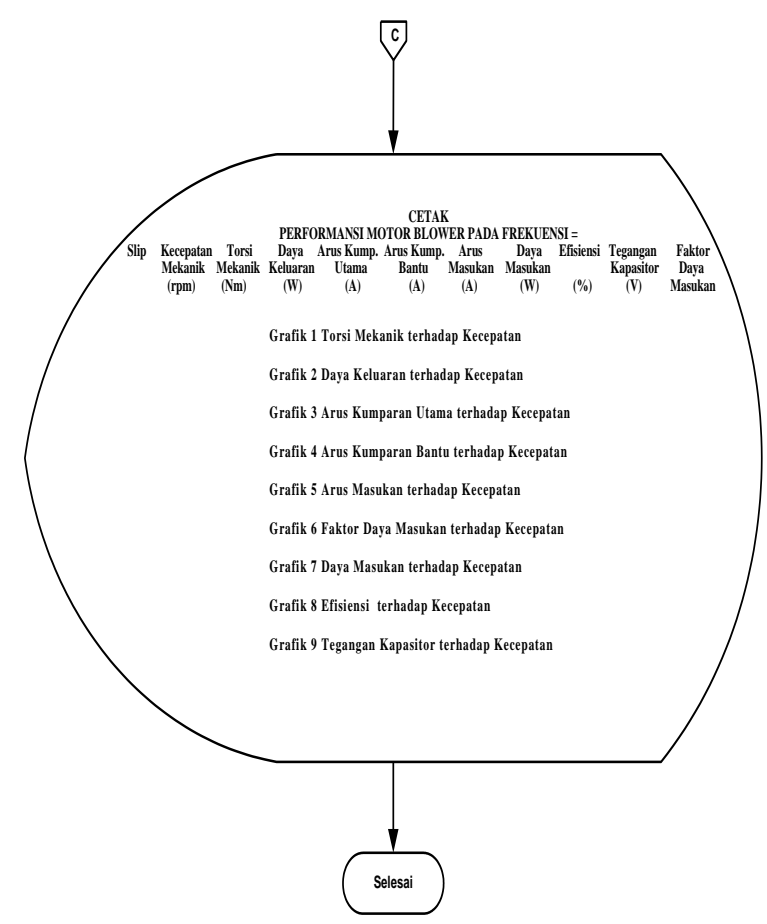


Mhd. Fahmi Syawali Rizki, Analisis Performansi Motor Induksi Satu Fasa Dengan Perbandingan

PERHITUNGAN

MOTOR INDUKSI SATU FASA PADA

BLOWER DENGAN SUPLAI DAYA V/f

KONSTAN DENGAN PROGRAM

MATLAB

Perhitungan performansi motor induksi satu fasa pada aplikasi blower menggunakan Bahasa Pemograman Matlab yang merupakan bahasa pemograman yang dapat dipakai untuk komputasi teknik. Di dalamnya terdapat kemampuan penghitungan, visualisasi dan pemograman dalam suatu lingkungan yang mudah untuk digunakan, karena permasalahan dan pemecahannya dinyatakan dalam notasi matematika biasa.

Berikut program Matlab untuk perhitungan performansi motor induksi satu fasa pada aplikasi blower untuk frekuensi 34 $\mathrm{Hz}$ sampai $50 \mathrm{~Hz}$ :

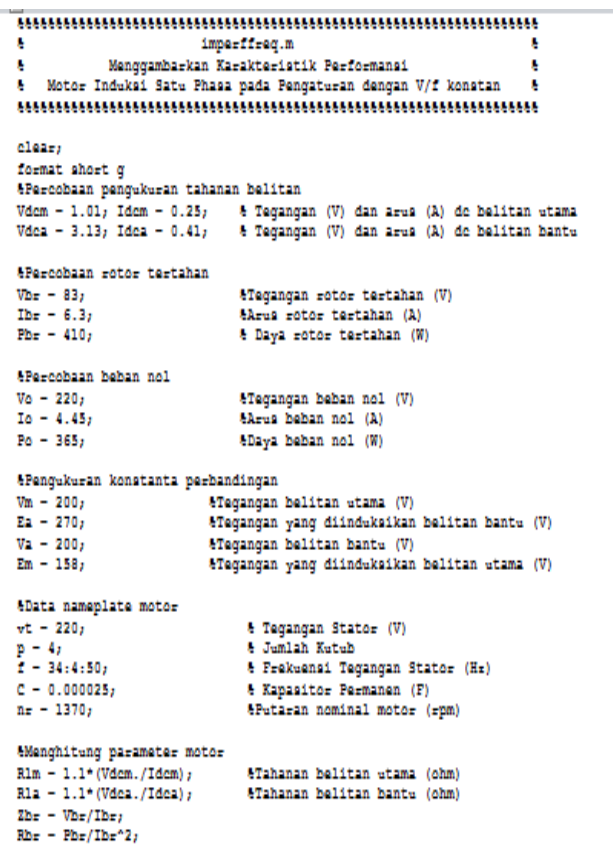

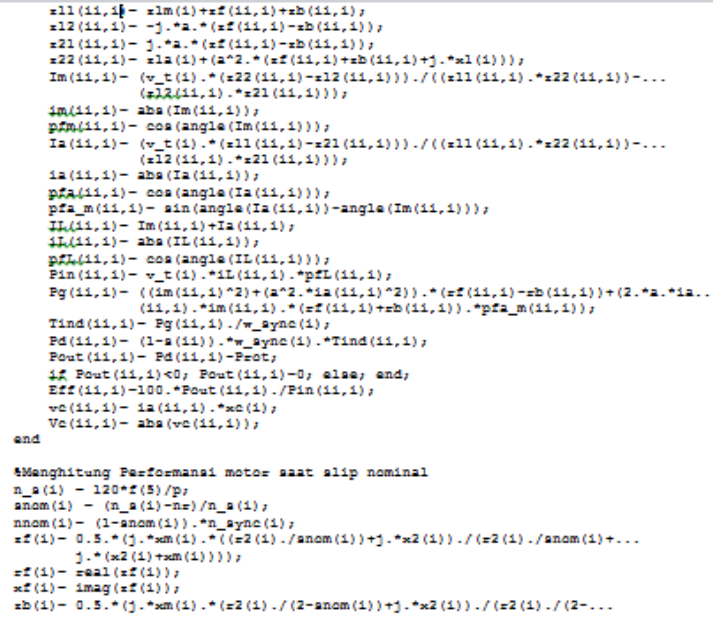

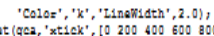

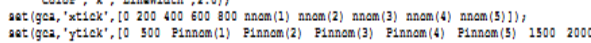

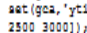

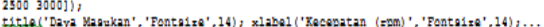

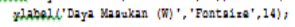

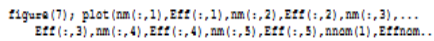

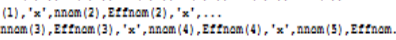

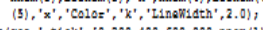

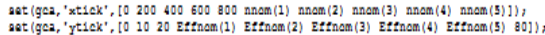

titles'

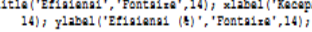

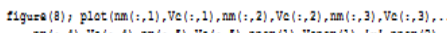

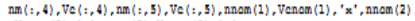

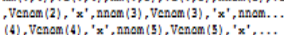

'Coloz', 'k', 'Lineoridets', 2.0),

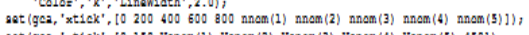

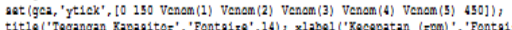

14), ylabe1 ('Tagangan Rapanitor (V)', 'Fonto1 ze', 14),

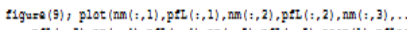

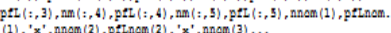

ptrnom (3), ' $x$ ', nnom (4), prinom (4), ${ }^{x}$ '

, nnam (5), petinam (5), ...

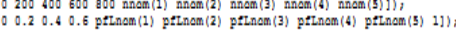

-

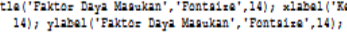

and 


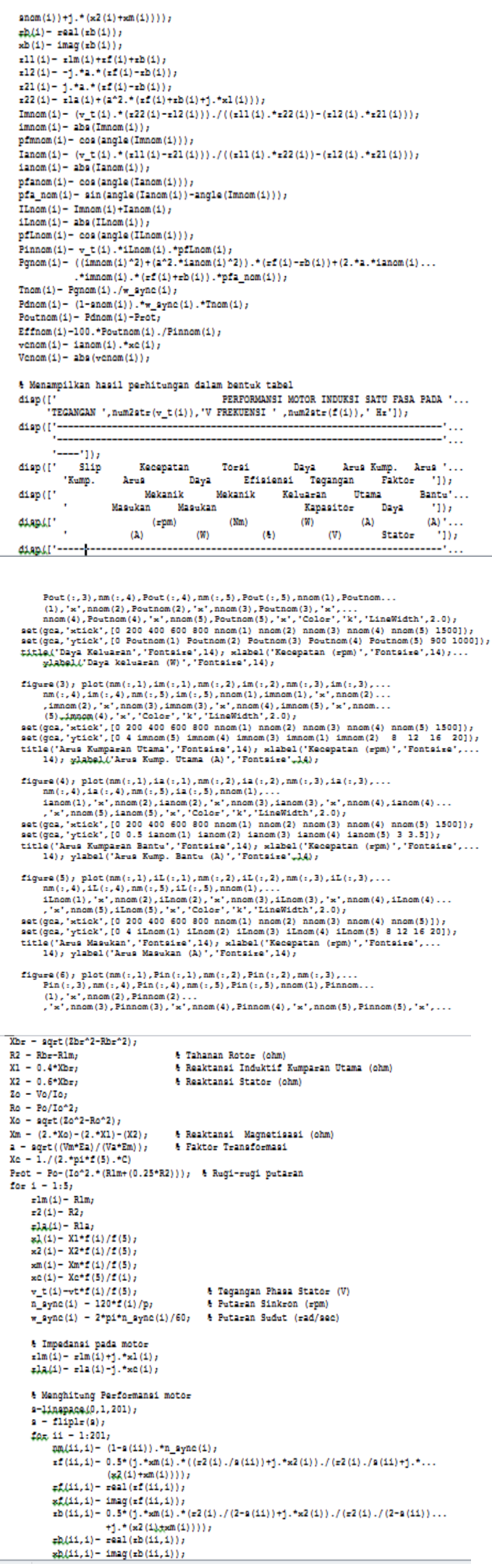

Dengan menjalankan program bmV/fkonstan.m di atas diperoleh keluaran berupa grafik seperti yang ditunjukkan pada Gambar 11 sampai dengan Gambar 19. Data secara keseluruhan dapat dilihat pada Tabel data

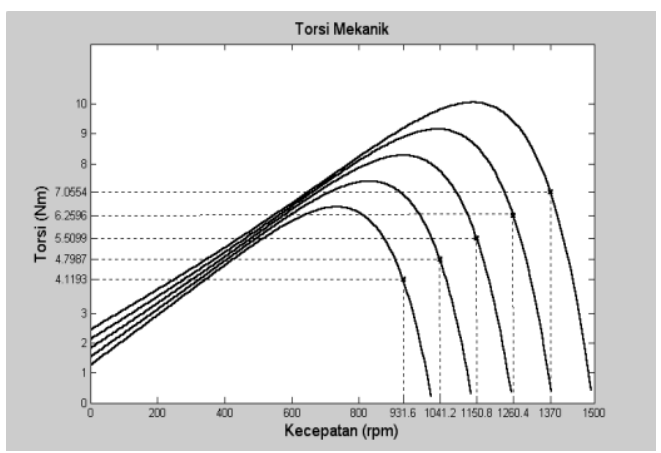

Gambar 11 Grafik Torsi Terhadap Kecepatan

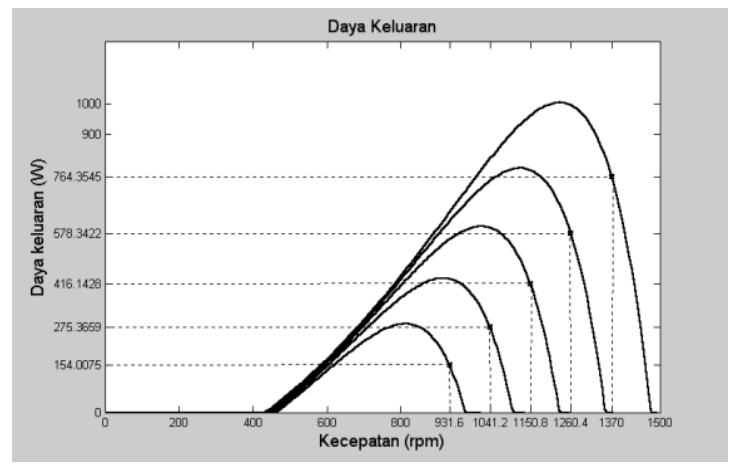

Gambar 12 Grafik Daya Keluar Terhadap Kecepatan

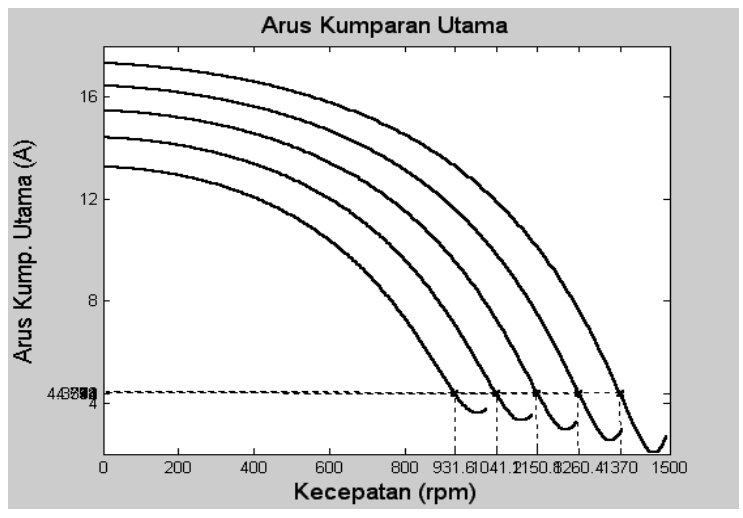

Gambar 13 Grafik Arus Kumparan Utama Terhadap Kecepatan 
Mhd. Fahmi Syawali Rizki, Analisis Performansi Motor Induksi Satu Fasa Dengan Perbandingan

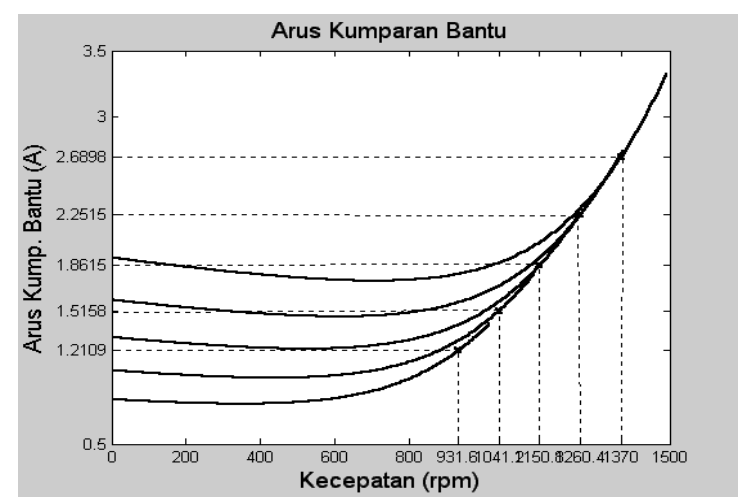

Gambar 14 Grafik Arus Kumparan Bantu Terhadap Kecepatan

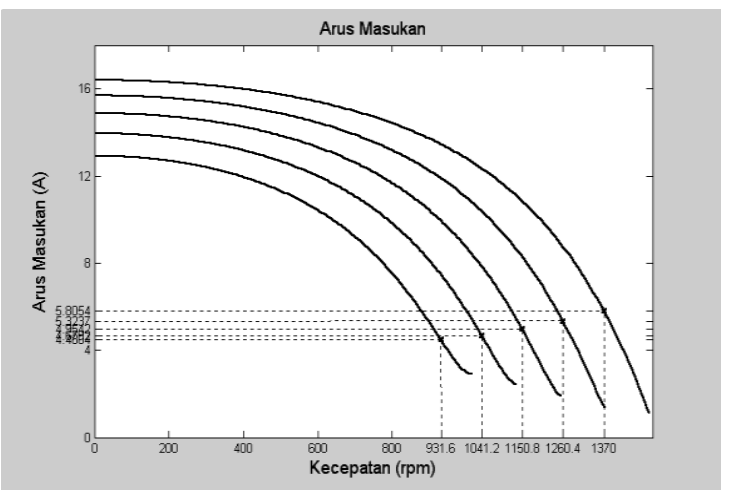

Gambar 15 Grafik Arus Masukan Terhadap Kecepatan

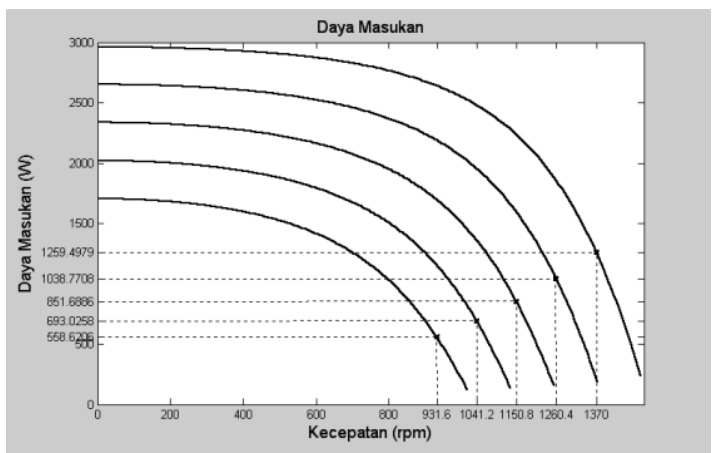

Gambar 16 Grafik Daya Masukan Terhadap

Kecepatan

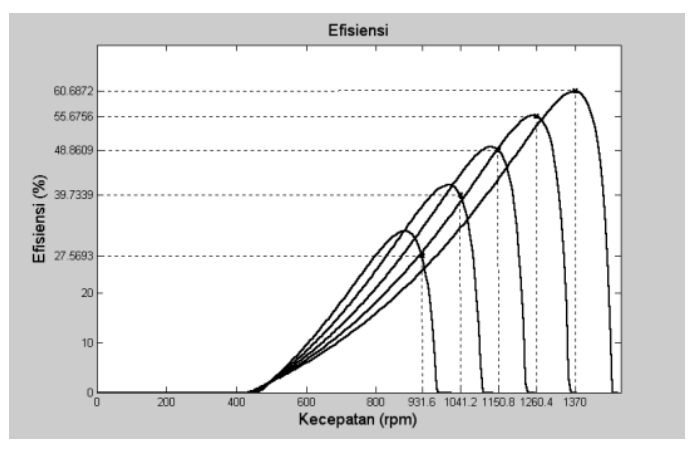

Gambar 17 Grafik Efisiensi Terhadap Kecepatan

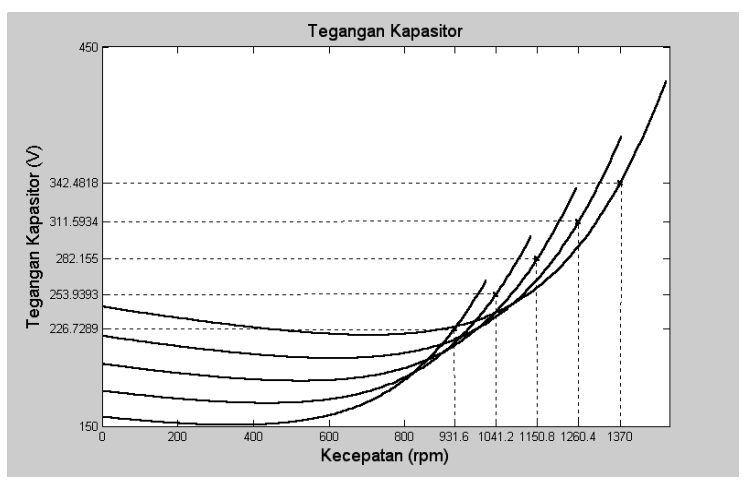

Gambar 18 Grafik Tegangan Kapasitor Terhadap kecepatan

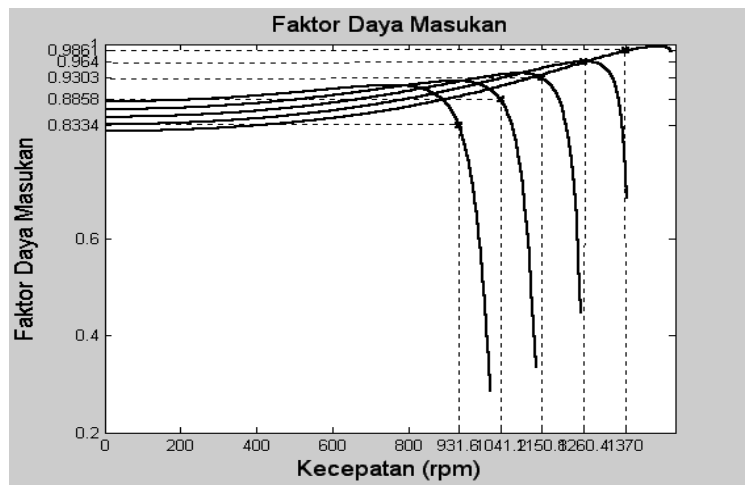

Gambar 19 Grafik Faktor Daya Stator Terhadap

Kecepatan

Dan dari data-data itu kita peroleh data performansi saat motor beroperasi pada 
putaran nominalnya yaitu 1370 rpm. Datadata tersebut adalah,

Slip $=0.087$

Faktor Daya Masukan $=0,986$

Kecepatan Mekanik $=1370$

Rpm Daya Masukan $=1262.88 \mathrm{~W}$

Torsi Mekanik $=7.06 \mathrm{Nm}$

Arus Masukan $=5.82 \mathrm{~A}$

Daya Keluaran $=762,58 \mathrm{~W}$

Arus Kumparan Utama $=4.355 \mathrm{~A}$

Effisiensi $=75.32 \%$

Arus Kumparan Bantu $=2.69$ A .

Tegangan Kapasitor $=342.49 \mathrm{~V}$

Tabel 3 Performansi Motor Induksi Satu Fasa Pada Torsi Nominal $=7.06 \mathrm{Nm}$

\begin{tabular}{|c|c|c|c|c|c|c|c|c|c|c|c|c|}
\hline $\begin{array}{l}\text { Teg. } \\
\text { M) }\end{array}$ & $\begin{array}{c}\text { Frek. } \\
(\mathrm{Hz})\end{array}$ & Sip & $\begin{array}{l}\text { Kec. } \\
\text { Meksnik } \\
(\mathrm{pmm})\end{array}$ & $\begin{array}{c}\text { Toris } \\
\text { Neksnik } \\
\text { (M) }\end{array}$ & $\begin{array}{l}\text { Deys } \\
\text { Kelugran } \\
\text { (M) }\end{array}$ & $\begin{array}{l}\text { Anvs } \\
\text { Kumpargn } \\
\text { Ulams }(A)\end{array}$ & $\begin{array}{l}\text { Anvs } \\
\text { Kumporsn } \\
\text { Bantu (A) }\end{array}$ & $\begin{array}{l}\text { Aus } \\
\text { Masukgn } \\
\text { (A) }\end{array}$ & $\begin{array}{l}\text { Dgys } \\
\text { Mgsukgn } \\
\text { (M) }\end{array}$ & $\eta(x)$ & $\begin{array}{l}\text { Teg. } \\
\text { Kap. } \\
\text { M }\end{array}$ & $\begin{array}{l}\text { Faktor } \\
\text { Dayg } \\
\text { Stitior } \\
\text { M) }\end{array}$ \\
\hline 149.6 & 34 & . & 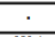 & $\cdot$ & & 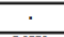 & $\cdot$ & & $\cdot$ & $\cdot$ & 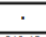 & 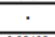 \\
\hline 167.2 & 38 & 0.19 & 923.4 & \begin{tabular}{|l|l|}
7.0554 \\
\end{tabular} & 434.39 & 7.2772 & 1.2741 & 7.6618 & $\begin{array}{l}1183.7 \\
\end{array}$ & 36.697 & 213.45 & 0.92402 \\
\hline 184.8 & 42 & 0.135 & 1089.9 & 7.0581 & 557,72 & 6.055 & 1.694 & 6.6906 & 1162.1 & 47.993 & 256.77 & 0.93987 \\
\hline 202.4 & 46 & 0.105 & 1235.1 & 7.0209 & 660.22 & 5.1287 & 2.1632 & 6.0997 & 1188.6 & 55.547 & 299.37 & 0.96275 \\
\hline 220 & 50 & 0.085 & 1372.5 & 6.9701 & 753.93 & 4.2678 & 2.7007 & 5.7257 & 1242.7 & 60.668 & 343.86 & 0.98657 \\
\hline
\end{tabular}

Tabel 4 Performansi Motor Induksi Satu Fasa Pada Torsi Maksimal

\begin{tabular}{|c|c|c|c|c|c|c|c|c|c|c|c|c|}
\hline $\begin{array}{l}\text { Teg. } \\
\text { M }\end{array}$ & $\begin{array}{c}\text { Frek. } \\
(\mathrm{Hz})\end{array}$ & Slip & $\begin{array}{l}\text { Keo. } \\
\text { Mekgnik } \\
\text { (pmm) }\end{array}$ & \begin{tabular}{|c} 
Torsi \\
Meksnik \\
(M)
\end{tabular} & $\begin{array}{l}\text { Days } \\
\text { Kelugran } \\
\text { (M) }\end{array}$ & $\begin{array}{l}\text { Ans } \\
\text { Kumporan } \\
\text { Utams (A) }\end{array}$ & $\begin{array}{c}\text { Anus } \\
\text { Kumparan } \\
\text { Bantu }(A)\end{array}$ & $\begin{array}{l}\text { Anss } \\
\text { Masukan } \\
\text { (A) }\end{array}$ & $\begin{array}{c}\text { Days } \\
\text { Masukan } \\
\text { (M) }\end{array}$ & $\eta(x)$ & $\begin{array}{l}\text { Teg. } \\
\text { Ksp. (N }\end{array}$ & \begin{tabular}{|c|} 
Fikhor \\
Dgya \\
Stitior \\
(M)
\end{tabular} \\
\hline 149.6 & 34 & 0.28 & 734.4 & 6.554 & 256.18 & 8.444 & 0.92886 & 8.7167 & \begin{tabular}{|l|l}
1193.5 \\
\end{tabular} & 21.465 & 173.92 & 0.91526 \\
\hline 167.2 & 38 & 0.27 & 832.2 & \begin{tabular}{|l|l|l|} 
\\
\end{tabular} & 3988.34 & 9.0834 & 1.1554 & 9.354 & \begin{tabular}{|l|l}
1437.2 \\
\end{tabular} & 27,717 & 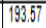 & 0.91891 \\
\hline 184.8 & 42 & 0.26 & 932.4 & 8.2801 & 5600.62 & 9.5644 & 1.4107 & 9.9438 & \begin{tabular}{|l|l}
16966.6 \\
\end{tabular} & 33.044 & 213.83 & 0.92326 \\
\hline 202.4 & 46 & 0.25 & 1035 & \begin{tabular}{|l|l}
9.1554 \\
\end{tabular} & 744.45 & 9.9738 & 1.6975 & 10.493 & 1972.2 & 37,748 & 234.93 & 0.92859 \\
\hline 220 & 50 & 0.24 & 1140 & 10.048 & 951.63 & 10.312 & 2.0193 & 11.012 & 2265.3 & 42.01 & 257.11 & 0.93502 \\
\hline
\end{tabular}

\section{KESIMPULAN}

Berdasarkan hasil analisis dan uraian pada bab-bab sebelumnya, dapat diambil beberapa kesimpulan sebagai berikut :

1. Motor induksi satu fasa pada blower jika dioperasikan di bawah frekuensi ratingnya dengan perbandingan suplai daya V/f konstan memiliki banyak variasi kecepatan dengan torsi beban yang berubah-ubah.

2. Pada kondisi torsi nominal, motor akan mengeluarkan daya yang lebih rendah saat beroperasi dengan frekuensi rendah dibandingkan dengan pada saat beroperasi pada frekuensi rating.

3. Pada kondisi torsi nominal, penurunan frekuensi akan menyebabkan arus yang mengalir pada motor akan semakin besar, oleh karena itu penurunan frekuensi yang dilakukan jangan terlalu besar agar tidak melebihi kemampuan arus motor.

4. Faktor daya masukan dan tegangan pada kapasitor motor cenderung akan menurun jika beroperasi pada frekuensi rendah.

5. Efisiensi motor akan semakin rendah jika beroperasi pada frekuensi yang rendah. 
Mhd. Fahmi Syawali Rizki, Analisis Performansi Motor Induksi Satu Fasa Dengan Perbandingan

\section{DAFTAR PUSTAKA}

A. L. Julian, R. S. Wallace, P. K. Sood, “Multi_Speed Control of Single Phase Induction Motors for Blower Applications", IEEE Trans. On Power Electronics, vol.10, no.1, pp.72-77, January 1995.

Bhag S. Guru, Huseyin R. Hiziroglu, "Electric Machinery and Transformers", Harcourt Brace Javanovich, San Diego, 1988.

Cathey, Jimmie J., Electricmachines : Analysis and Design Applying Matlab, McGraw Hill, Boston, 2001.

Chapman, Stephene J., Electric Machinery Fundamentals, Third Edition, McGraw Hill Companies, New York, 1999.

Fitzgerald, Charles Kingsley JR., Mesin-Mesin Listrik, Edisi Keenam, Erlangga, Jakarta, 1993.

Soelaiman,Ts. MHD, Mesin Tak Serempak Dalam Praktek, Pradnya Paramitha, Jakarta, 1995.

Theraja, B.L., A Text Book of Electrical Technology, $17^{\text {th }}$ Revised Edition, S.Chand \& Company Ltd., Ram Nagar, New Delhi, 1979 